Article

\title{
Public Agency in Changing Industrial Circular Economy Ecosystems: Roles, Modes and Structures
}

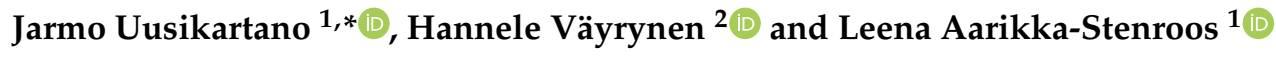 \\ 1 Center for Innovation and Technology Research, Unit of Industrial Engineering and Management, \\ Faculty of Management and Business, Tampere University, Korkeakoulunkatu 8, 33720 Tampere, Finland; \\ leena.aarikka-stenroos@tuni.fi \\ 2 Unit of Information and Knowledge Management, Faculty of Management and Business, \\ Tampere University, Korkeakoulunkatu 8, 33720 Tampere, Finland; hannele.vayrynen@tuni.fi \\ * Correspondence: jarmo.uusikartano@tuni.fi; Tel.: +358-505-300-715
}

Received: 29 September 2020; Accepted: 25 November 2020; Published: 30 November 2020

check for updates

\begin{abstract}
Value creation in the circular economy (CE) is a result of co-creation. In the industrial context, the theme of collaboration has been studied extensively on a company-to-company basis, but related public agency remains unexplored. Still, circular actions happen in societal contexts where public actors and logics are constantly present, enabling the change toward more sustainable actions. For systematic discovery of the topic, the following research questions are considered: (a) What roles can a public actor have in an industrial CE ecosystem? (b) What are the relationship modes a public actor can have? (c) In what kind of actor structures may the roles and modes occur? The study relies on two multiple case studies in the international (Study 1) and Finnish eco-industrial parks (Study 2) contexts. The results are based on qualitative content analysis conducted with both primary and secondary data. As a result, six distinct roles-operator, organizer, financer, supporter, policymaker, and regulator-and two modes—facilitative and dirigiste-for public agency in industrial CE ecosystems were identified. The roles depict the concrete means used by public actors whereas the modes depict the characteristics of these actions. Finally, exemplar organization models for the recognized roles and modes in industrial CE ecosystems were examined. The study provides insights into how public actors can contribute to sustainability transitions among their territories and helps practitioners to better understand the premises for public-private interaction.
\end{abstract}

Keywords: industrial circular economy ecosystems; agency; public actor; roles; modes; organization; collaboration

\section{Introduction}

In the circular economy (CE), the strategies of narrowing, slowing, and closing the resource loops (see [1]) are the result of co-creation among multiple actors and organizations, which often requires collaboration between the public sector and private business systems (see, e.g., [2]). For now, public and private actors have been considered separately within the fields of $C E$ research. For example, in urban, political and social ecology, public strategies [3], the relation between public policy and business [4,5], social movements [3,6], public innovations [3] and drivers for CE [4] have been studied. The field of industrial ecology, instead, has primarily focused on the physical flows and production of energy and matter between industrial and natural systems (see, e.g., [7-9]), including examinations of industrial ecosystems, eco-efficiency, cleaner production, zero waste, and natural capitalism [10]. In addition, industrial ecology considers the industrial and natural systems as a whole and concentrates very little on the organization of independent actors, especially public ones, within the systems. This paper aims to break the aforementioned dichotomies by examining the public agency involved 
and organized in the business interface. Since the resource flows that industries are operating with are often location-specific and occur within a certain public area, the issue of material circulations and organization becomes relevant for public actors responsible for the overall development of the area (e.g., urban planning performed by cities).

This study is positioned in the field of industrial ecology (e.g., [11-13]), as the aim is to study the roles of public agency in the context of local material flows and industrial symbioses occurring in industrial ecosystems and in the field of $\mathrm{CE}$ research; particularly, its streams discussing organizing and managing multi-actor systems for CE (e.g., [14-16]), as the study discusses how public actors aim to support and organize CE actions in regional industrial and urban CE systems. For now, some methods from disciplines other than engineering have been used in industrial ecology to understand the behavior of the relevant actors and organizations [9]. Currently, public actors have been recognized as playing a role in industrial CE ecosystems, but the nuances and different embodiments of that role remain uncharted. For example, Gibbs and Deutz [13] have noted that public policy intervention could play an enabling role in recognizing, initiating, and maintaining conditions for inter-firm networking in CE. Similarly, Chertow and Ehrenfeld [17] have recognized that public actors can facilitate inter-firm collaboration in CE. Furthermore, Aarikka-Stenroos et al. [14] have acknowledged the diversity of actors, including public actors, in CE ecosystems but have not analyzed public actor roles within them explicitly. This study examines further how the role of public agency in CE can manifest in practice.

Knowledge about public agency and its role in industrial CE actions is lacking, calling for studies on the public sector role in CE ecosystems [18]. Apart from social studies and in addition to the industrial ecology field, the public actor is studied here as a part of the economic-technological structure of industrial CE ecosystems, i.e., how public actor involvement and organization manifest in the business interface within an industrial CE ecosystem. This take on multi-actor organizations in CE also contributes to organization studies, as it considers the ways in which multiple actors collaborate for $\mathrm{CE}$ and the yet unexplored characteristics and models of such organizing (see $[17,19])$. All industrial actions take place in societal contexts, and the public sector can therefore catalyze the sustainability transition [11], for example, through public laws, policies, procurement processes, and authorization protocols (e.g., [20,21]). Moreover, the public actor can define what is to be considered as sustainable and preferable actions within its territory (see, e.g., [5]). Public agency is therefore inherently critical in industrial CE actions that are usually strongly local and place-specific. Furthermore, the pressure for sustainability also directly considers the public sector, and new urban revitalization is needed to support societies to obtain urban environmental, economic, and social sustainability with means such as Transit-Oriented Development (TOD) (see [22-24]). So, alongside private actors, public agency is also clearly involved in $\mathrm{CE}$ and industrial actions. This paper especially considers regionally manifested public agencies such as cities and local authorities and the way they contribute to environmental sustainability among/through their territories (e.g., public urban planning affecting the CE ecosystems that are evolving around local side streams and material flows) in the context of industrial CE ecosystems.

As Aarikka-Stenroos et al. [14] define, "A circular economy (CE) ecosystem is a multi-actor entity in which interdependent actors play complementary roles. The actors can include companies, industry actors, public and governmental actors such as cities and municipalities, and ministries, universities, non-profit organizations and citizen-consumers. A CE ecosystem emerges or is created around a common, system-level goal related to resource circularity, circular economy knowledge, or circular economy business and business models. The agency varies from focal actor-driven ecosystems to distributed agency, and ecosystem structure varies between tightly coordinated CE business models to loosely-coupled affiliation structures around CE-oriented goals." As this paper considers public agency in the nexus of industrial ecology and organizing for $\mathrm{CE}$, the focus is on industrial CE ecosystems linking to the general industrial ecology concept of an industrial system-"a particular configuration of stocks and flows of matter, energy, and information" [9]. However, industrial actions happen in social and urban contexts, which is an important issue to acknowledge: as expressed by industrial ecology terms, an industrial system and its environment form a joint ecosystem where the resource 
flows happen [7]. Industrial CE ecosystems are therefore considered here as a part of a wider urban and social context, namely cities.

By combining and adapting Aarikka-Stenroos et al.'s [14] concepts of "industrial" and "urban" CE ecosystems, "industrial CE ecosystem" in this paper refers to a location-specific community of hierarchically independent, yet interdependent actors (such as companies, municipalities, associations, citizens) aiming for environmentally sustainable energy and material flows through optimizing and innovating with material flows and stocks (see [4]) in symbiotic collaboration and by utilizing/contributing/reacting to the wider urban operating environment within which they are located. Industrial CE ecosystems are furthermore place- and time-dependent physical set-ups providing place-specific needs and assets (see, e.g., $[14,25]$ ) related to the ecosystem. All industrial CE ecosystem actors and materials do not need to be collocated, nor can they as some resources (e.g., rare minerals) and producers are not locally available. This means that the boundaries of an industrial CE ecosystem can vary between different resources. Nevertheless, the ecosystem is characterized by issues specific to a certain area (such as available local side streams or the transport costs of rarer raw materials to that specific area). The writers acknowledge that these issues also include social and economic concerns alongside the environmental ones (for examples on public agency-related social and economic aspects in CE, see $[5,6,26]$ ) and involve a larger group of actors than just public actors and companies (such as citizens; see $[5,6])$. Important here are the questions related to public actors as users of power within their territories: how the power is distributed, how different stakeholders are included or excluded in the public decision-making and actions, or how local material resilience and stocks should be supported in relation to the feasibility radius of material flows. However, these considerations are not covered further here, as the paper concentrates on environmental sustainability and public agency from industrial and organizational points of view.

A way to support industrial CE ecosystems is to strengthen collaboration activities between companies as well as between companies and government (e.g., [19]). The activities include closing the material loops, reducing the resources needed, and preserving the materials in the loops as long as possible [27]. Indeed, the ecosystems approach is highly relevant, as in industrial CE ecosystems, the presence and influence of public agency and collaboration between public and private actors is clearly visible. Namely, in industrial CE ecosystems, companies often contribute to sustainability targets set by the prevailing social context and public actor (for examples, see [3,5,10]). Industrial CE ecosystems encompass a broad variety of physical and social settings (e.g., [6]) in which CE applications take place and that in the discipline have been classified as "eco-industrial parks", "green industrial parks", "eco-clusters", "industrial recycling networks," or "eco-centers" (see [28-30]). This study examines eco-industrial parks (EIPs) for enabling concrete and hands-on considerations of public agency in industrial CE ecosystems. EIPs also relate closely to sustainability change agencies, as they have been referred to as a strategy for developing and establishing CE [31], even as a requirement for implementing CE on the meso level [7]. However, in EIPs, the micro level meets the macro level as single collocated companies collaborate with the representatives of the local city. Based on this variety of agencies and referring to Aarikka-Stenroos et al.'s [14] definition, EIPs are seen as representations of industrial CE ecosystems in this paper.

Since the forms of public agency in industrial CE ecosystems have not yet been studied properly, the purpose of this study is to provide new knowledge on the avenues for public presence and influence in industrial CE ecosystems. The research considers how public actors can contribute to achieving and promoting environmental sustainability-oriented $\mathrm{CE}$ operations among their territories. Public agency in industrial CE ecosystems is examined in the context of EIPs, which are arguably the most studied industrial CE ecosystems where public and private actors often pursue environmental goals and innovations together (e.g., [32,33]). Moreover, EIPs involve change agency, as most of them have emerged through an eco-transformation of an existing industrial ecosystem [34].

The research deliberates on two studies. Study 1 presents an extensive multiple case study based on secondary data of 20 industrial CE ecosystem cases around the world. Through the study, the roles (research question 1) and modes (research question 2) for public actors in industrial CE ecosystems are 
recognized. In Study 2, the recognized roles and modes are analyzed further through a focused and longitudinal multiple case study on four Finnish industrial CE ecosystem cases. Moreover, the second study explores and showcases the organizational structures (research question 3) in which the different public actor roles and modes may emerge in industrial CE ecosystems.

This paper aims to illustrate the different roles, modes, and organizational structures of public agency in industrial CE ecosystems. The research questions as well as research methods are described in Section 3. After that, the results of the study are presented in Section 4. From the literature and empirical results, six roles for public actors were identified: operator, organizer, supporter, financer, policymaker, and regulator. In these roles, the actor can have two different modes: facilitative or dirigiste. Finally, the ways the roles and modes are organized in industrial CE ecosystems are illustrated. The paper contributes both to academic research and practice by providing a more comprehensive perception of public agency in the industrial CE operation field. The contributions, as well as the recommendations, research limitations, and ideas for future research, are discussed in Section 5.

\section{Theoretical Background}

This study focuses explicitly on public agency in industrial CE ecosystems. The premised used for the study is the recent research by Ingstrup et al. [35], which examined the alignment and misalignment between institutional logics of academia, industry, and governance in CE. Ingstrup et al. see circular actions as arrangements between these three actor types. Moreover, they state that the alignment in institutional logics can happen at three levels: actor-type (collaboration within one actor type), relationship (collaboration between two actor types), and systems (inter-organizational collaboration between at least three actor types at the same time). In this study, public agency in industrial CE ecosystems is considered within these three levels by discovering the roles of a public actor, the relationship types within the roles, and the organization structures formed by the roles and relationships.

\subsection{Different Roles and Contexts for Public Actors}

There are different ways for public involvement to actualize in industrial CE ecosystems. This is seen in the vague suggestions about different public actor roles in CE. Avenues for public involvement in industrial CE ecosystems cover at least economic, legislative, coordinating, and political mechanisms (see, e.g., [20,21]) in which the actor can be present in a formal or informal manner. The public actor acts as a support system around which the development of industrial CE ecosystems could be built (see [8]) or even shape the institutional environment to promote sustainable actions [5,36]. Furthermore, it is suggested that governments should facilitate industrial symbiosis (IS) actions in order to promote an overall transition toward CE [11]. Thus, the public actor seems to have several means for setting the tone for industrial CE ecosystems.

Currently, the scientific literature presents two main strategies for pursuing CE. These strategies refer to the first places where CE strategies became prominent, namely China and Europe (see, e.g., [37]). The strategies have a differing approach to $\mathrm{CE}$, which also affects the roles and nature of public actors and their ways of interacting with the private sector. The CE strategy China is following is characterized by a national political strategy that drives sustainable actions top-down [7]. The strong political CE agenda is steered by environmental concerns and the impacts they have on the national economy (e.g., bad environmental image and its effects on foreign trade-related factors [38]). To simplify, this "business based on CE" strategy refers to pollution and sustainable development issues that are addressed by asking how to do business in a sustainable way. Instead, in the CE strategy generally followed in Europe, $\mathrm{CE}$ is a tool for developing bottom-up politics related to environmental policies and waste management issues, the focus being on waste management policies [7]. The driving rationale for $\mathrm{CE}$ in this strategy is in economic competitiveness and innovations as much as in environmental aims [37]. To simplify, this "better environment as a spin-off from business" CE strategy concentrates on wastes and the possibilities they provide for the industries by considering how to do business out of sustainability. 
Although they have their origins in China and Europe, the presented CE strategies are not limited to these territories. Moreover, they are not dichotomous, and hybrids of these strategies occur: the Japanese EIP "Kawasaki Zero-Emission Industrial Complex," for example, is based on a national Eco-Town program that includes elements from both the aforementioned CE strategies. Under the Eco-Town program of Kawasaki, the local government has guided the local industries toward innovative environmentally friendly recycling actions by supporting the diversification of existing aging conventional industry clusters and attracting investments from lighter industries [39]. Therefore, in Kawasaki there are elements both from "business based on CE" strategy, such as strong presence of the public actor and financial support from the national government, and "better environment as a spin-off from business" strategy, such as the program based on voluntary actions by companies and financial gain potential as the main driver for inter-organizational collaboration.

The different policies and means used in them suggest there can be different roles emerging within an industrial CE ecosystem. Moreover, different roles can occur simultaneously within the same industrial CE ecosystem: public authorities often have many roles such as administrator, investor, planner, and facilitator [21]. The portfolio of means and liabilities recognized for public actors in industrial CE ecosystems is broad, yet unstructured. Therefore, the research question (RQ) that needs to be considered further is:

RQ1: What roles can a public actor have in an industrial CE ecosystem?

\subsection{The Ways of Public Involvement in Industrial CE Ecosystems}

The presence of the public actor in industrial CE ecosystems is acknowledged in the scientific literature. Ghisellini et al. [7] state that CE concerns all actors in society and the models of collaboration and exchange between them. Indeed, CE has seen some justice, democracy, and equity-related challenges among different stakeholders (see [6]), which calls for better examination of the different actors in CE. Many researchers emphasize the importance of public actors to foster CE through politics, national initiatives, economic incentives, environmental legislation, and raising awareness [7,40]. In the context of industrial CE ecosystems, researchers state that publicly supported or promoted EIPs adopt more sustainable practices than those with limited public support [19]. For instance, at the beginning of the Chinese EIP Rizhao Economic and Technology Development Area (REDA), 28 circular actions out of 31 happened under the guidance of public administration in one way or another [20]. On the other hand, some researchers see the public actor as an inhibitor when, for example, the current legislation is too fixed for new circular experiments. According to Fischer and Pascucci [41], old and inflexible legislation and linear economy-based investment criteria constrain innovative actions within CE.

CE scholars still do not agree how significant the role of a public actor should be in industrial CE ecosystems. Mulrow et al. [12] state that public actors' involvement in the circular actions of companies can have both positive and negative consequences. According to Wang et al. [29], local government can have a vital role in creating and sustaining IS networks in China, although other actors are also needed. Moreover, Yu et al. [21] claim that suitable policy instruments, together with a combination of publicly controlled and organically developed actions, may encourage the transformation of industrial ecosystems into eco-industrial ones. Overall, there is some debate about the superiority between government policy and a free market approach in CE [42], and the discussion continues. Therefore, it is worth examining how public agency really currently actualizes in industrial CE ecosystems.

RQ2: What are the relationship modes a public actor can have toward an industrial CE ecosystem?

\subsection{Organization and Structures of Industrial CE Ecosystems}

In industrial CE ecosystems, different actors cooperate with each other in order to produce industrial goods and services through symbiotic resource use [14]. The way industrial CE ecosystems enhance the collaboration between CE actors in practice is through material exchanges and knowledge 
flows that provide new insights or benefits (societal, environmental and/or economic) for the participants. For example, in EIPs, the actors within and outside the park form networks of collaboration where the interactions between the actors happen [19]. This indicates that circular actions are multidimensional and involve multiple actors by their nature.

The multidimensionality increases the complexness of the ecosystems, which is usually managed by a central actor who is the main responsible driving and coordinating the industrial CE ecosystem. Herczeg et al. [30] even note that the presence of a central actor distinguishes CE ecosystems from other collaborating networks. The central actor has been referred to by many names, such as "network entrepreneur," "hub firm," "lead organization," "champion," "network administrative organization," "anchor tenant," and "orchestrator" [15]. Here, the term "central organization" is used when referring to this type of actor.

From a public agency point of view, industrial CE ecosystems such as EIPs provide "a laboratory for the creation of policy and regulations that are more effective for the environment while less burdensome to business" [32]. Although the presence of public agency in industrial CE ecosystems has been widely recognized among CE scholars, the interaction between public and private actors could still be examined closer. Namely, the current literature on CE business models presumes that the business model boundaries coincide with a single firm's boundaries [43]. This ignores the fact that $\mathrm{CE}$ ecosystems consist of multiple collaborating public and private actors due to symbiotic benefits (e.g., [29]). In this collaborative setting aiming for sustainability, the perspective of public agency and business structures is highly relevant, as public actors contribute to the context-the local territory and operating environment-in which CE business takes place (see, e.g., [5]). For private actors in turn, a better understanding of successful business models in CE requires exploring the various forms of collaboration and innovations among different actors [16], including public actors.

While the different collaborating actors have been studied individually, a structured and comprehensive examination of industrial CE ecosystems in industrial ecology is missing. Researchers do refer to the ecosystem level in their studies on collaboration and organization in CE (see, e.g., [13,17]), but the concrete roles of public actors within industrial CE ecosystems are still unclear and obscure: for example, what kind of public entities are involved in the ecosystems, the significance of public agency in them, or how the businesses and administration are situated in relation to public actors. Instead, research on industrial CE ecosystems remains fragmented [42], and there are hardly any characterizations for the organizational models of industrial CE ecosystems [17,19], or knowledge or illustrations on the industrial CE ecosystem structures (e.g., [44]). There do exist mapping analyses on the resource loops between operations [45], the relations between sustainability indicators [46], the enterprise architecture and hierarchy [47], and the infrastructure of a specific market [48]. Even in this case, there are no illustrations or detailed mappings about industrial CE ecosystem structures from the public actors' point of view. Therefore, it remains to be explored:

RQ3: In what kind of actor structures may the public actor roles and modes occur in an industrial CE ecosystem?

\section{Methods}

Reflecting the levels of Ingstrup et al.'s [35] model, this study deliberates in three research questions what roles (RQ1) and modes (RQ2) public agency may have in an industrial CE ecosystem, and what kind of structures (RQ3) the public agency may form in the ecosystem. The research unfolds in two studies. In Study 1, an extensive multiple case study through secondary data of 20 industrial CE ecosystem cases was conducted in order to sketch the diversity of public actor roles and modes in industrial CE ecosystems. Then, in Study 2, a focused multiple case study of four Finnish industrial $\mathrm{CE}$ ecosystem cases was performed to analyze and showcase the public agency roles and modes in detail in the focal industrial CE ecosystem and explore the related organizational structures.

In both studies, a multiple case study was seen as a natural fit for the purpose, as it is "a strategy for doing research which involves an empirical investigation of a particular contemporary 
phenomenon within its real-life context using multiple sources of evidence" [49] (p. 5). When selecting the cases for Studies 1 and 2, a purposeful sampling strategy was chosen in the form of theoretical sampling. The aim of this research was to develop rather than test a theory, for which purpose the theoretical sampling is an appropriate method [50]. This deductive approach involves finding case manifestations of the studied theoretical construct that help to examine and elaborate the construct, its variations, and its implications [51] (p. 288). For the unit of analysis, EIP was deemed as a unit best representing an industrial CE ecosystem in practice at the moment: In EIPs, public agency is evident (for examples, see [11,32,52]), and EIPs furthermore provide an illustrative setting to examine public agency in real-life action. Furthermore, EIPs have been intensively studied and documented during the last few years (see [7]), providing a good basis for Study 1. When examining the public actor roles, modes, and organization structures in industrial CE ecosystems, qualitative analysis methods were used, namely adapted principles of qualitative content analysis and typological analysis. Qualitative designs often serve as the first step in analyzing a phenomenon and should be further developed by quantitative approaches when necessary [53]. Next, the application of the chosen research methods in Studies 1 and 2 is described in detail.

\subsection{Study 1: Extensive Multiple Case Study}

First, an extensive multiple case study based on qualitative secondary data of 20 industrial CE ecosystem cases around the world was conducted in order to widely explore the public roles (RQ1) and modes (RQ2) in industrial CE ecosystems. The case selection in Study 1 was based on the EIP lists provided by Gibbs and Deutz [13], Erkman and Van Hezik [54], and Bellantuono et al. [19], as well as the data availability and representativeness of the cases. In qualitative studies, typically the focus is on a relatively small sample selected for a quite specific purpose [51] (p. 264). For this purpose, 20 was considered a sufficient number of cases to be studied.

The chosen 20 cases were studied through existing secondary data, which is a common and acknowledged source of information to be used [55] (p. 103). As the observed cases are based on secondary data provided by other researchers, the chosen cases were the ones most studied in the field and therefore included a great deal of existing knowledge. When choosing the cases, a preliminary aim of gathering ten cases representing "better environment as a spin-off from business" CE strategy and ten cases representing "business based on CE" $C E$ strategy was set. This is because these strategies were considered to represent two major (opposite) CE strategies. This is why the very Western-oriented EIP lists were manually complemented by four Asian cases, namely Kawasaki Zero-Emission Industrial Complex, Rizhao Economic and Technology Development Area (REDA), Suzhou Industrial Park (SIP), and Ulsan Eco-industrial Park. As a result of the case selection, 20 cases that represent almost evenly the aforementioned CE strategies were chosen for further examination. The cases are presented in Table 1 below.

Table 1. Study 1: Analyzed industrial circular economy ecosystem cases with their primary source material.

\begin{tabular}{ccc}
\hline Name of the Case & Domicile & Primary Source Material \\
\hline Burnside Industrial Park & Canada & {$[56]$} \\
Dalian Development Area (DDA) & China & {$[21]$} \\
Devens Eco-Industrial Park & USA & {$[57]$} \\
Ecopark Hartberg GmbH & Austria & {$[58]$} \\
Guitang Group & Japan & {$[59]$} \\
Kajisawa Eco-industrial Park, EBARA Corporation of Japan & China & {$[60]$} \\
Kawasaki Zero-Emission Industrial Complex & Denmark & {$[61]$} \\
Kwinana Industrial Area (KIA) & Japan & {$[39]$} \\
Nanning Sugar Co., Ltd. & Australia & {$[62]$} \\
National Industrial Symbiosis Programme (NISP) & China & {$[63]$} \\
Rizhao Economic and Technology Development Area (REDA) & United Kingdom & {$[15]$} \\
Santa Cruz & China & {$[20]$} \\
\hline
\end{tabular}


Table 1. Cont.

\begin{tabular}{ccc}
\hline Name of the Case & Domicile & Primary Source Material \\
\hline Shenyang Economic and Technological Development Zone (SETDZ) & China & {$[65]$} \\
Suzhou Industrial Park (SIP) & China (Singapore) & {$[33]$} \\
Tianjin Economic-Technological Development Area (TEDA) & China & {$[29]$} \\
Uimaharju Industrial Ecosystem & Finland & {$[66]$} \\
Ulsan Eco-industrial Park & South Korea & {$[67]$} \\
Value Park & Germany & {$[68]$} \\
Vreten Park & Sweden & {$[68]$} \\
\hline
\end{tabular}

When examining the public actor roles and modes in industrial CE ecosystems, adapted principles of qualitative content analysis and typological analysis were used. Here, the inductive approach, in which particular instances are observed and then combined into a larger unit [69], was used. Following this method, the case material was first analyzed, and issues of public involvement labeled based on the public measures used, and their purpose (e.g., financial instruments for preserving the system) and the way they were used (e.g., carrot vs. stick set-up). The labels were then combined into bigger, distinct themes. This resulted in six roles and two modes for public agency in industrial CE ecosystems that were then used for typological analysis.

In typological analysis, the researcher first identifies an organizing framework [70], which is then used for processing and categorizing the data to be collected. For this purpose, the concepts of roles and modes are based on the levels of actor-type and relationship in Ingstrup et al.'s [35] model of alignment levels in institutional logics. Against the organizing framework-here the roles and modes - the cases are grouped, empirical regularities examined [71], and possible commonalities searched [70]. The found examples of public actor involvement in the 20 industrial CE ecosystem cases were categorized into the roles and modes based on the most prevalent means and nature of interaction the public actor had in each setting. As a result, a table of examples for both modes in each role was created (see Section 4.1).

\subsection{Study 2: Focused Multiple Case Study}

In Study 2, a focused longitudinal multiple case study of four Finnish industrial CE ecosystem cases with good research access was conducted, which provided a deep understanding of how the public roles and modes actualize in an industrial CE ecosystem, and how the system functions and is structured. Therefore, Study 2 has a twofold purpose. First, it validates the findings in Study 1 by closely examining and showcasing the public actor roles and modes within the same industrial CE ecosystem in four well-known cases. While Study 1 on the 20 international cases provided a sketch of the roles, modes, and a list of actions that can be executed by the same or different public actors, Study 2 concentrates on examining what kind of public institutions can (co-)exist and what kind of actions each of them can actually perform. Second, Study 2 explores the structures the different roles and modes may emerge in, i.e., public agency on the system level (RQ3).

Study 2 relied on four Finnish industrial CE ecosystem cases chosen based on access to data and pre-assumptions of their very high representativeness of the studied phenomenon. Studying Finnish cases was seen to provide a highly representative picture of the latest avenues of public agency in industrial CE ecosystems, since Finland has been generally recognized as one of the leading countries in CE globally. Finland was, for example, the first country in the world to have a national road map to $\mathrm{CE}$ [72], and the Finnish Innovation Fund Sitra was selected as the winner of the public-sector category of the Circulars Awards in 2018 [73].

The cases were studied hands-on through ethnographic follow-up during the period of May 2017-September 2019. This included, for example, regularly meeting representatives of the industrial CE ecosystems, attending workshops organized by them, and visiting the ecosystem locations. In addition, ten interviews with key actors (three from top management, four from development, two from operations, and one from research) from each case were conducted. For comprehensive understanding of each case, the primary data was complemented by secondary data such as public 
documents (e.g., written reports of city government or committee decisions or strategy policies) and EIP-specific reports (e.g., magazines, reports, or annual reports). The cases with related data sources are presented in Table 2.

Table 2. Study 2: Analyzed industrial circular economy ecosystem cases and related data sources.

\begin{tabular}{|c|c|c|c|c|}
\hline Name of Case & $\begin{array}{l}\text { Central (Public) } \\
\text { Organization }\end{array}$ & $\begin{array}{l}\text { Interviews with } \\
\text { Key Actors }\end{array}$ & $\begin{array}{l}\text { Observation, } \\
\text { Ethnography }\end{array}$ & $\begin{array}{c}\text { Secondary Source } \\
\text { Material }\end{array}$ \\
\hline $\begin{array}{l}\text { Ekomo eco-industrial } \\
\text { centre, Ämmässuo }{ }^{1} \text {; } \\
\text { Helsinki Region, } \\
\text { Finland }\end{array}$ & $\begin{array}{l}\text { Helsinki Region } \\
\text { Environmental } \\
\text { Services Authority } \\
\text { HSY }\end{array}$ & 2 & $\begin{array}{l}\text { Visiting the park; } \\
\text { attending a workshop } \\
\text { discussion; attending an } \\
\text { online workshop (2); } \\
\text { free-form discussion } \\
\text { with a key actor; } \\
\text { attending monthly } \\
\text { meetings on project } \\
\text { updates (ca. 20) }\end{array}$ & $\begin{array}{l}\text { Annual reports; } \\
\text { completions of the city } \\
\text { council and other } \\
\text { institutes; news; web } \\
\text { pages; seminar } \\
\text { presentation by the } \\
\text { central organization }\end{array}$ \\
\hline $\begin{array}{l}\text { Rusko Waste } \\
\text { Treatment Centre }{ }^{2} \text {; } \\
\text { Oulu, Finland }\end{array}$ & Kiertokaari Ltd. & 3 & $\begin{array}{l}\text { Visiting the park; } \\
\text { attending monthly } \\
\text { meetings on project } \\
\text { updates (ca. 20); } \\
\text { free-form discussions } \\
\text { with key actors; } \\
\text { attending an online } \\
\text { workshop }\end{array}$ & $\begin{array}{l}\text { Annual reports; } \\
\text { completions of the city } \\
\text { council and other } \\
\text { institutes; news; web } \\
\text { pages; seminar } \\
\text { presentations by the } \\
\text { central organization (3) }\end{array}$ \\
\hline $\begin{array}{l}\text { ECO3 Kolmenkulma } \\
\text { Eco-Industrial Park }{ }^{3} \text {; } \\
\text { Nokia, Finland }\end{array}$ & Verte Ltd. & 2 & $\begin{array}{l}\text { Visiting the park; } \\
\text { attending workshop } \\
\text { discussion (4); free-form } \\
\text { discussion with key } \\
\text { actors; attending } \\
\text { meetings of the park } \\
\text { members and } \\
\text { stakeholders (2) }\end{array}$ & $\begin{array}{l}\text { Annual reports; } \\
\text { completions of the city } \\
\text { council and other } \\
\text { institutes; news; web } \\
\text { pages; journal article; } \\
\text { project report; seminar } \\
\text { presentations by the } \\
\text { central organization (3) }\end{array}$ \\
\hline $\begin{array}{l}\text { Topinpuisto Circular } \\
\text { Economy Hub } \\
\text { Turku, Finland }\end{array}$ & $\begin{array}{l}\text { Lounais-Suomen } \\
\text { Jätehuolto Ltd. }\end{array}$ & 3 & $\begin{array}{l}\text { Attending monthly } \\
\text { meetings on project } \\
\text { updates (ca. 20); } \\
\text { attending an online } \\
\text { workshop }\end{array}$ & $\begin{array}{l}\text { Annual reports; } \\
\text { completions of the city } \\
\text { council and other } \\
\text { institutes; news; } \\
\text { web pages }\end{array}$ \\
\hline
\end{tabular}

kiertokaari/ruskon-jatekeskus/; ${ }^{3}$ https://eco3.fi/en/; ${ }^{4}$ https://www.topinpuisto.fi/en/.

The decision to have different cases for system-level observations in Study 2 was based on two main factors. First, studying the inner organization mechanisms of a system requires longitudinal knowledge and access to data throughout. This was achieved by selecting easily accessible cases that the researchers had already collaborated with. Secondly, using different cases between Studies 1 and 2 provided a possibility for data triangulation, improving the validity of the research.

In Study 2, the concentration was on the system level of Ingstrup et al.'s [35] model of alignment levels in institutional logics. As in Study 1, adapted principles of qualitative content analysis were used when analyzing the four Finnish industrial CE ecosystem cases for ecosystem structures. First, a schema of the overall organizational structure for each of the cases was created. Then, the structures were further analyzed with an emphasis on public actors and their roles and modes in the ecosystems. Conducting the overall organizational review first and the analysis on the roles and modes only after that ensured the study was not led by the presumptions of the researchers. As a result, examples of the relations between different public roles, modes, and organizational structures were recognized. Study 2 therefore shows how the recognized roles and modes can be situated in an industrial CE ecosystem and how the ecosystem is structured. For analyzing and illustrating the relationships between the studied industrial CE ecosystem actors, a software program Kumu (https://kumu.io/) for visual network mapping was used. The illustrations are shown in Figures 1 and 2, in which a combination of the findings from all four cases are presented. The figures show both the business and administration structures between the ecosystem members. 


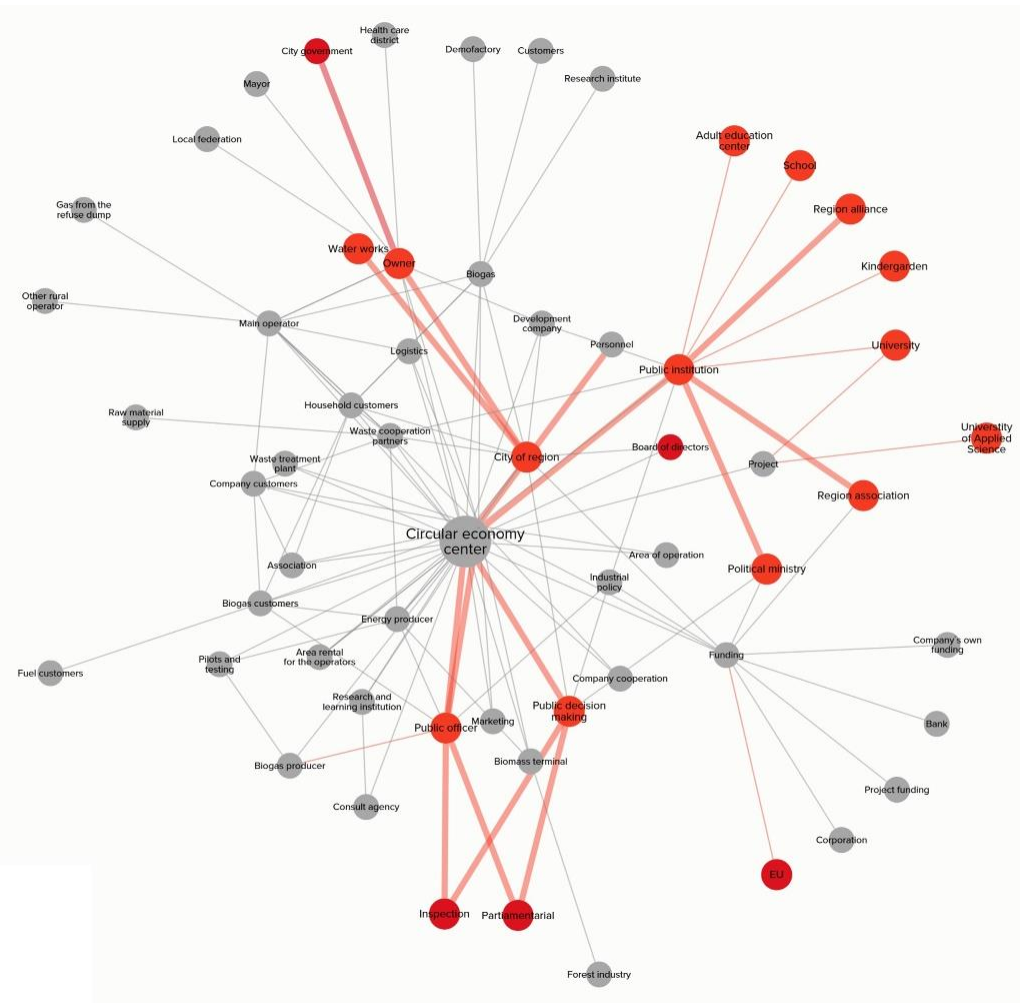

Figure 1. Administration structures between public and private actors in the examined four Finnish industrial CE ecosystem cases. The most permanent relationships and public actors are shown in red, while other ecosystem actors are illustrated in gray.

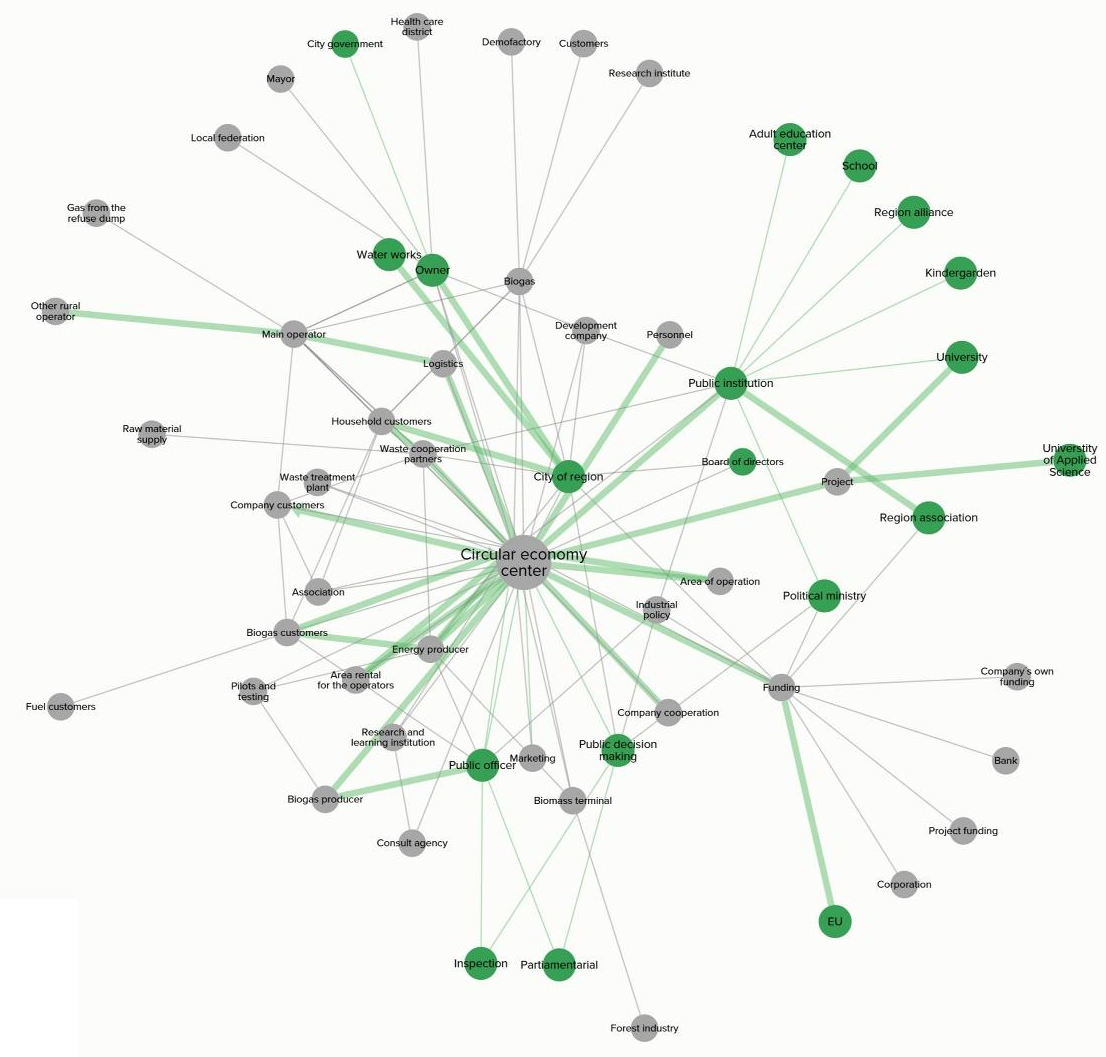

Figure 2. Business transaction structures between public and private actors in the examined four Finnish industrial CE ecosystem cases. The most permanent relationships and actors are shown in green, while other ecosystem actors are illustrated in gray. 


\section{Results}

\subsection{Roles of Public Agency in Industrial CE Ecosystems}

Based on the case study of 20 industrial CE ecosystems in Study 1, six clear distinct roles of public agency in industrial CE ecosystems were identified and later validated in Study 2, which contributes to research question 1 . The roles differ from each other on the basis of the avenues and means through which a public actor influences/contributes to the actions that happen in the ecosystem. This way, the roles simultaneously present different interfaces for public-private interaction, i.e., they are avenues for public actors to intervene in industrial CE ecosystems. The six roles for a public actor to play in industrial CE ecosystems are operator, organizer, financer, supporter, policymaker, and regulator. The roles and related mechanisms and field of engagement are presented in Table 3. The roles correspond to the actor-type level in Ingstrup et al.'s [35] model of the levels of alignment as they explain in detail the different types of public actors occurring on the actor-type level. It must be noted that the same public actor can have several roles at the same time, and there can be several public actors (e.g., local municipality, government, public servants) having different or overlapping roles within the same ecosystem.

The operator contributes to the operative functions of an industrial CE ecosystem. In other words, the actions of the operator affect how the system functions on a daily basis. The means of interaction are mostly managemental, including both more imperative (e.g., the development of old industrial area guided by local authority; public departments assessing, accepting, and inspecting the system members) and collaborative approaches (e.g., public departments promoting, building, and maintaining IS with a partner-like mentality; environmental services provided for the system members).

The organizer concentrates on the organizational structure of an industrial CE ecosystem and how its operations are organized. The organizer contributes to the setting, vision, and goals of the ecosystem and can even be the initial force launching the industrial CE ecosystem (e.g., state legislature created a commission to plan the reuse of the old industrial area; the system was established by the local municipality). The organization contribution can happen through collaborative acts such as shared public-private management of the ecosystem (e.g., a department of the local municipality is responsible for excursions to the otherwise privately organized ecosystem). On the other hand, the organizer can have direct controlling and guiding actions within the ecosystem (e.g., formal agreements on sustainability goals with companies; selecting the operator).

The financer is responsible for the public finance actions implemented toward the industrial CE ecosystem. The means cover financial incentives such as ready-made public infrastructure or beneficial energy prices for companies to move toward sustainability. More direct financial support for the ecosystem members is also possible. This support for the ecosystem also includes direct investments such as financial support toward voluntary sustainability actions, funding for sustainability projects, covering the costs of the ecosystem operator, or providing services free of charge for the members.

The supporter provides support functions for industrial CE ecosystems. Usually, the supporter is physically located outside of the ecosystem and has partner-like interaction with it. The supporter can have by-product exchanges and contracts with the ecosystem companies, or there can be state-owned enterprises located in the ecosystem. The supporter participates in a collaborative/consultative manner in actions that promote and enhance sustainable actions in the industrial CE ecosystem (e.g., public research institutes offering their expertise for companies; mutual development projects with companies).

The policymaker shapes the sustainability policy/agenda implemented in the industrial CE ecosystem. The means vary from national environmental and sustainability policies to regional IS programs and system-specific agendas. The policies and programs can be co-developed together with system members or executed top-down (e.g., acceptance of a company to a national program; public plans of transforming old industrial areas into green ones; national policies guiding the development of the ecosystem). The policymaker often oversees that the ecosystem actions are aligned with public sustainability policies. According to these local/regional/national policies, a policymaker 
may have concentrated, for example, on resources considered abundant or scarce (e.g., available space, biomasses, renewable energy) within its territory.

Table 3. The identified roles, modes and examples of public agency in industrial CE ecosystems.

\begin{tabular}{|c|c|c|}
\hline \multirow{2}{*}{ Role } & \multicolumn{2}{|r|}{ Mode } \\
\hline & Facilitative & Dirigiste \\
\hline \multirow[t]{3}{*}{ Operator } & $\begin{array}{l}\text { The operator of the park belongs to a local } \\
\text { university. (Burnside Industrial Park, [56]) }\end{array}$ & $\begin{array}{l}\text { In the park, there are different public-based } \\
\text { departments that, e.g., assess the environmental } \\
\text { impacts of the park attendees, determine whether } \\
\text { an attendee or project is approved to the park or } \\
\text { not, and monitor as well as perform environmental } \\
\text { inspections in the park. (SIP, [33]) }\end{array}$ \\
\hline & $\begin{array}{l}\text { The commission created by the state } \\
\text { legislature guided the redevelopment of the } \\
\text { old military base through regulatory and } \\
\text { permit-granting actions. Alongside, a } \\
\text { quasi-state agency manages the } \\
\text { infrastructure, public services, and the sale } \\
\text { and leasing of real estate within the area. } \\
\text { (Devens Eco-Industrial Park, [57]) }\end{array}$ & $\begin{array}{l}\text { In the park, there are different departments formed } \\
\text { by the local authority. They, e.g., coordinate and } \\
\text { manage the park, measure the pollution rates of the } \\
\text { companies, facilitate inter-firm IS opportunities, } \\
\text { and organize the dispersed knowledge resources in } \\
\text { the park. (TEDA, [52]) }\end{array}$ \\
\hline & $\begin{array}{l}\text { The program, executed by } 12 \\
\text { semi-autonomous regional offices, } \\
\text { performed actions from promoting and } \\
\text { building the IS network to maintaining and } \\
\text { co-developing it. (NISP, [15]) }\end{array}$ & $\begin{array}{l}\text { The main operator of the park is a local } \\
\text { government-owned non-profit organization that } \\
\text { provides environmental services for local } \\
\text { companies. It is the core of the IS coordination } \\
\text { network, as it acts as a collaboration platform } \\
\text { between government departments and foreign } \\
\text { organizations. (TEDA, [29]) }\end{array}$ \\
\hline \multirow[t]{6}{*}{ Organizer } & $\begin{array}{l}\text { The state legislature created a commission } \\
\text { to plan the reuse of the base, i.e., to generate } \\
\text { vision and goals for the park. (Devens } \\
\text { Eco-Industrial Park, [57]) }\end{array}$ & $\begin{array}{l}\text { The park was established by the local municipality. } \\
\text { (Ecopark Hartberg } \mathrm{GmbH},[58] \text { ) }\end{array}$ \\
\hline & $\begin{array}{l}\text { A department of the local municipality } \\
\text { handles the secretary and visitors of the } \\
\text { area. (Kalundborg Symbiosis, [74]) }\end{array}$ & $\begin{array}{l}\text { The park was founded by the local municipality. } \\
\text { (Vreten Park, [68]) }\end{array}$ \\
\hline & \multirow{4}{*}{$\begin{array}{l}\text { The local municipality facilitates contacts } \\
\text { between the park members. (Ecopark } \\
\text { Hartberg GmbH, [58]) }\end{array}$} & $\begin{array}{l}\text { The park was established when industries located } \\
\text { in the industrial district signed a formal agreement } \\
\text { with the government to be part of a state } \\
\text { government initiative aiming for sustainable } \\
\text { development. (Santa Cruz, [64]) }\end{array}$ \\
\hline & & $\begin{array}{l}\text { The park is a government-to-government project } \\
\text { between two countries. In practice, the park is } \\
\text { located in one country, but it has been } \\
\text { co-developed together with other countries that } \\
\text { have special knowledge on the subject. (SIP, [33]) }\end{array}$ \\
\hline & & $\begin{array}{l}\text { The eco-transformation of the park has been } \\
\text { government-driven and guided by national } \\
\text { environmental policies. (TEDA, [29]) }\end{array}$ \\
\hline & & $\begin{array}{l}\text { The operator of the park is selected by companies } \\
\text { and the local municipality government. (Ulsan } \\
\text { Eco-industrial Park, [67]) }\end{array}$ \\
\hline
\end{tabular}


Table 3. Cont.

\begin{tabular}{|c|c|c|}
\hline \multirow{2}{*}{ Role } & \multicolumn{2}{|r|}{ Mode } \\
\hline & Facilitative & Dirigiste \\
\hline \multirow[t]{4}{*}{ Financer } & $\begin{array}{l}\text { The local government provides financial } \\
\text { incentives for the development of IS. } \\
\text { (REDA, [20]) }\end{array}$ & $\begin{array}{l}\text { The public actors at the municipality, province, } \\
\text { and federal levels together cover the costs of the } \\
\text { main operator of the park. (Burnside Industrial } \\
\text { Park, [56]) }\end{array}$ \\
\hline & $\begin{array}{l}\text { The local municipality offers the } \\
\text { infrastructure and beneficial energy prices } \\
\text { for the park members. (Ecopark Hartberg } \\
\text { GmbH, [58]) }\end{array}$ & \multirow{3}{*}{$\begin{array}{l}\text { Major deal in program funding came from the } \\
\text { government, with the aim of finding new ways to } \\
\text { remain economically competitive under the } \\
\text { changing and tightening regulatory environment. } \\
\text { (NISP, [15]) }\end{array}$} \\
\hline & $\begin{array}{l}\text { The eco-transformation of the area was } \\
\text { based on voluntary actions performed by } \\
\text { the enterprises and financially supported by } \\
\text { the national government. (Kawasaki } \\
\text { Zero-Emission Industrial Complex, [39]) }\end{array}$ & \\
\hline & $\begin{array}{l}\text { The actions and services the national IS } \\
\text { program provided were free of charge for } \\
\text { the companies. (NISP, [15]) }\end{array}$ & \\
\hline \multirow[t]{7}{*}{ Supporter } & $\begin{array}{l}\text { The park-located services such as shops, } \\
\text { cafés, law offices and cinema are used by } \\
\text { the park members and the inhabitants of } \\
\text { the municipality. (Ecopark Hartberg } \\
\text { GmbH, [58]) }\end{array}$ & $\begin{array}{l}\text { The municipal wastewaters are treated in the } \\
\text { park's wastewater plant. The park also sells } \\
\text { surplus electricity to the national grid. (Uimaharju } \\
\text { Industrial Ecosystem, [66]) }\end{array}$ \\
\hline & $\begin{array}{l}\text { There are by-product exchanges and steam } \\
\text { and heat contracts between the park } \\
\text { companies and the local municipality. } \\
\text { (Kalundborg Symbiosis, [61]) }\end{array}$ & \multirow{6}{*}{$\begin{array}{l}\text { The over } 1300 \text { enterprises located in the park also } \\
\text { include state-owned enterprises. (SETDZ, [65]) }\end{array}$} \\
\hline & $\begin{array}{l}\text { The municipal waste collection has been } \\
\text { involved in recycling projects in the area. } \\
\text { (Kawasaki Zero-Emission Industrial } \\
\text { Complex, [39]) }\end{array}$ & \\
\hline & $\begin{array}{l}\text { In the park, the involved companies form } \\
\text { groups that study and resolve social, } \\
\text { environmental, and economic problems, } \\
\text { which ultimately leads to strong } \\
\text { public-private relationships that benefit } \\
\text { both the companies and the local } \\
\text { community. (Vreten Park, [68]) }\end{array}$ & \\
\hline & $\begin{array}{l}\text { The operator of the park liaises with the } \\
\text { public authorities and other stakeholders. It } \\
\text { has, for example, collaborated with a } \\
\text { technological university to enhance the } \\
\text { realization of IS in the park. (KIA, [62]) }\end{array}$ & \\
\hline & $\begin{array}{l}\text { The national environment agency worked } \\
\text { together with the program to build } \\
\text { awareness of IS. (NISP, [15]) }\end{array}$ & \\
\hline & $\begin{array}{l}\text { The local authorities have also participated } \\
\text { directly in IS promotion. For example, the } \\
\text { local government has organized a society of } \\
\text { ecological companies. (REDA, [20]) }\end{array}$ & \\
\hline
\end{tabular}


Table 3. Cont.

\begin{tabular}{ll}
\hline \multirow{2}{*}{ Role } & \multicolumn{1}{c}{ Facilitative } \\
\cline { 2 - 3 } Policymaker & $\begin{array}{l}\text { The local authorities and coordinating } \\
\text { entities have tried to answer the needs } \\
\text { and challenges of the park companies } \\
\text { through sustainability policies, } \\
\text { regulations, and programs. (Devens } \\
\text { Eco-Industrial Park, [57]) }\end{array}$ \\
\hline $\begin{array}{l}\text { The program was the first national-level } \\
\text { IS program in the world. The aim was to } \\
\text { promote IS as a key policy tool for the } \\
\text { industry and government to help the } \\
\text { whole country reach a sustainable economy. } \\
\text { (NISP, [15]) }\end{array}$ \\
\hline
\end{tabular}

The frames for the EIP program were co-developed by the environmental protection agency of the city, state government, local university, community, and private sector constitutions. (Santa Cruz, [64])
Mode

The park was established by the state legislature as an act to reuse the former military base. (Devens Eco-Industrial Park, [57])

The park is a result of the redevelopment aims of the local industrial properties initiated by the local municipality and supported by the federal government, the EU, and the local district. (Ecopark Hartberg GmbH, [58])

The park area has been allocated to companies by local authorities based on the aspect of leading environmental technologies and practices.

(Kawasaki Zero-Emission Industrial Complex, [39])

The vital force for the redevelopment of the industrial area was the governmental eco-town program. The program aimed to ground innovative recycling actions within the aging conventional industry clusters. Under the program, the local government has guided the local industries toward more environmentally friendly actions. (Kawasaki Zero-Emission Industrial Complex, [39])

The park became a national demonstration EIP, as it was selected by the national commission. (DDA, [21])

The national guidelines create a frame based on which the management of the park has created its own guidelines to help accomplish the sometimes strictly binding national policy goals. (DDA, [21])

The park was approved as a national eco-industrial demonstration park due to its good compliance with national policies. (Guitang Group, [60])

The strong national policies toward pollution prevention and resource efficiency have guided the development agenda of the private park. (Nanning Sugar Co., Ltd., [63])

The transformation of the park toward an eco-industrial one has been strongly led by national policies, according to which the management committee of the park has developed the park concept. Moreover, in the early phase, most of the IS performances were formed through the direct or indirect guidance of the governmental agenda. (REDA, [20])

Alongside the national policies, the local city government has set its own policies for sustainability and designed its own implementation plans to develop CE within its area. (REDA, [20]) 
Table 3. Cont.

\begin{tabular}{|c|c|c|}
\hline \multirow{2}{*}{ Role } & \multicolumn{2}{|r|}{ Mode } \\
\hline & Facilitative & Dirigiste \\
\hline & & $\begin{array}{l}\text { The park has been established according to } \\
\text { national economic and technological policies. } \\
\text { There is a strong national agenda guiding the park. } \\
\text { (SETDZ, [65]) }\end{array}$ \\
\hline & & $\begin{array}{l}\text { The national policies are accompanied by } \\
\text { province-level policies, such as a fund for } \\
\text { implementing cleaner production procedures in the } \\
\text { companies. (SETDZ, [75]) }\end{array}$ \\
\hline & & $\begin{array}{l}\text { The park is part of an ongoing national } \\
\text { development project, where the aim is to transfer } \\
\text { traditional industrial parks into eco parks. The } \\
\text { 15-year EIP plan has concrete steps according to } \\
\text { which the industrial parks are being transformed. } \\
\text { (Ulsan Eco-industrial Park, [67]) }\end{array}$ \\
\hline \multirow[t]{5}{*}{ Regulator } & $\begin{array}{l}\text { The park's symbioses are to some extent the } \\
\text { result of recycling-oriented thinking that } \\
\text { has its grounding in the local legislative } \\
\text { framework. (Kawasaki Zero-Emission } \\
\text { Industrial Complex, [39]) }\end{array}$ & $\begin{array}{l}\text { The main economic motives for the park companies } \\
\text { to pursue IS are strict regulations, tax preferences, } \\
\text { financial subsidies, and benefits from material } \\
\text { substitution. (REDA, [20]) }\end{array}$ \\
\hline & \multirow{4}{*}{$\begin{array}{l}\text { The municipal government has accredited a } \\
\text { committee to lead the development and } \\
\text { management of the park. The committee } \\
\text { does not have legislative rights, but it } \\
\text { implements guidelines and policies in the } \\
\text { park. (DDA, [21]) }\end{array}$} & $\begin{array}{l}\text { The somewhat strict and demanding national } \\
\text { legislation concerning the sustainable development } \\
\text { of the sugar industry affects the actions of the park. } \\
\text { (Guitang Group, [60]) }\end{array}$ \\
\hline & & $\begin{array}{l}\text { In the park, there have been strong actions toward } \\
\text { cleaner production in order to comply with the } \\
\text { national legislation and maintain a good } \\
\text { environmental image. (SETDZ, [65]) }\end{array}$ \\
\hline & & $\begin{array}{l}\text { There is a lot of regulation directly guiding the } \\
\text { actions the park departments, especially the public } \\
\text { ones, pursue. Overall, the regulation in the park } \\
\text { has increased and become more demanding. } \\
\text { It even pushes the companies to implement more } \\
\text { environmentally friendly actions in their } \\
\text { production. (SIP, [33]) }\end{array}$ \\
\hline & & $\begin{array}{l}\text { The national government has determined strict } \\
\text { standards for the environmental quality of the } \\
\text { industries in the park. (Ulsan Eco-industrial } \\
\text { Park, [67]) }\end{array}$ \\
\hline
\end{tabular}

The regulator affects the industrial CE ecosystem through legislation and regulation regarding the ecosystem itself or its operations context. As laws are a result of the actions of national-level policymakers, the regulator role naturally has a strong connection to the role of policymaker. To justify the regulator as its own role: a public actor has the role of regulator when the public sustainability policies are integrated top-down into an industrial CE ecosystem in a certain, regulated manner. In a softer approach, legislation is used to guide and encourage ecosystem members toward sustainability. This means guidelines through which the regulator indirectly affects the ecosystem, for example, an ecosystem operator accredited by local authorities. In a more imperative approach, even strict regulation is targeted toward the ecosystem. Here, detailed rules and standards are used (e.g., strict rules for the environmental qualities of the ecosystem members; clear demands for IS; required compliance between the ecosystem actions and national legislation). 


\subsection{The Characteristics of the Relationships in Different Roles-The Two Modes}

In the identified six roles, the premises for public interaction seemed to vary regarding the means used and the nature of public-private relationships. In fact, two modes for public agency-facilitative and dirigiste-were recognized in Study 1, which contributes to research question 2. When the presented roles depict the public actions, the modes represent the characteristics of these actions. This way, the modes depict the nature of public-private relationships and correspond to the relationship level in Ingstrup et al.'s [35] model of the levels of alignment. The modes differ from each other based on the level (direct-indirect) and way (definitive-supportive) of involvement and engagement in the industrial CE ecosystem actions. In both modes, the public actor is active, but the means to interact with the ecosystem differ evidently. The modes and their nature in each of the six public actor roles are presented in the previously mentioned Table 2 . Here, the examples from the literature were categorized into the modes based on the most prevalent characteristics (either the level or way of involvement and engagement). This means, e.g., that the example categorized as dirigiste may be indirect but simultaneously very definitive, resulting in the mode dirigiste.

In the facilitative mode, the public actor uses indirect supportive and encouraging means to enhance CE actions in the ecosystem. The presence of public agency is not so prominent, but the public actor stimulates the ecosystem in the background. The public actor creates propitious frames, opportunities, and incentives such as infrastructure and environmental services for sustainable actions. The subtle means also include financial incentives, beneficial prices, sustainability-promoting legislation, and advisory CE road maps for companies. The facilitative public actor is usually located outside of the ecosystem, which naturally results in such collaborative interaction with the ecosystem where the public actor is a partner/customer of the ecosystem.

In the dirigiste mode, the public actor uses direct, somewhat imperative means to enhance CE actions in the ecosystem. The presence of public agency is definitive, and the public actor actively intervenes with the ecosystem. Moreover, the dirigiste actor is usually the initial force, the primus motor for the organization of the ecosystem. This presence often lasts after the initiation as well, and the dirigiste actor is present in the industrial CE ecosystem even in a physical manner (e.g., as the operator; public enterprises located in the ecosystem). In the ecosystem, the actor uses decision-making power and controls, manages, and assesses the ecosystem members. Alongside the controlling actions, the public actor can cover the costs of some environmental actions in the ecosystem or provide inputs such as wastewater for the companies. In the dirigiste mode, the public actor has a strong agenda based on public policies (e.g., urban planning of the local territories guiding the $\mathrm{CE}$ actions, designated locations for $\mathrm{CE}$ operations, and allocation of (scarce) lands; programs for transforming old industrial areas into eco ones; national eco-industrial demonstration park programs) and regulation (e.g., strict standards for emissions) that the ecosystem members must obey or are willing to obey in order to receive public fame and respect.

Although the facilitative and dirigiste modes are somewhat opposites of each other, they should not be seen as dichotomous. Namely, the same public actor can have different modes in different roles or even within the same role. Moreover, the division is not clear-cut, and the modes should be seen as two opposite ends of a continuum depicting the level and way of public engagement in industrial CE ecosystems. In fact, in the middle of this continuum, there is a more passive state where the public actor does not necessarily have significant implications in the ecosystem. There were occasions in the case sample where the public actor was not willing or able to promote circular actions. Such examples are Santa Cruz, where the public actor withdrew entirely from the ecosystem (see [64]), and Fujisawa Eco-industrial Park, EBARA Corporation of Japan (see [59]) and Value Park (see [68]), which are totally private projects. However, the "passive" mode needs to be addressed better in future studies.

\subsection{The Public Actor in Industrial CE Ecosystem Structure}

In Study 1, the six public actor roles found depict the means of influencing. The two modes in turn depict the ways the means are used. As the means and ways to use them vary, presumably the roles 
are also situated differently within an industrial CE ecosystem. Ingstrup et al. [35] found in their study that the third important level regarding institutional logics and the concept of alignment alongside the actor-type and relationship levels is the system level. In fact, the roles and modes of the public agency in industrial CE ecosystems actualize as interfaces for public-private collaboration. Promoting the actions considers not only public-private interaction, but also facilitates fruitful private-private confluences. Next, Study 2 examines public actors and agency position in industrial CE ecosystems by zooming in on the organizational structures of the ecosystems through four Finnish industrial CE ecosystem cases.

In Study 1, the roles and modes were identified from a vast, global, and complex sample, which enables their generalizability. However, this study alone does not provide a deep understanding of their occurrence within the same system. Therefore, Study 2 first validates the roles and modes by analyzing them closely in four Finnish industrial CE ecosystem cases. Simultaneously, Study 2 contributes to research question 3 , as the four cases examined show empirically how an industrial CE ecosystem functions and is structured, how public actors operate in the ecosystems, and how the roles actualize in the industrial CE ecosystem structure. As the emphasis is on observing the position of the roles, the results of the four cases are presented as combined illustrations where the examination is divided into two perspectives. In Figure 1, the administrative structures where the different public actor roles emerge are presented. The business transaction structures between the public roles and private companies are shown in Figure 2. In the figures, the most permanent relationships and actors are shown in red, while other industrial CE ecosystem actors are illustrated in gray (as the emphasis here is on public agency). Next, the administrative and business structures are depicted simultaneously in the following case descriptions, as they partly overlap. For each case, the most prevalent public actor in each role is considered.

In Case 1-Ekomo eco-industrial centre, Ämmässuo, the industrial CE ecosystem has basically evolved around a public waste management company, its surroundings, and its operations. The public company is the central organization, and has its own regulated waste treatment operations, but it offers the wide park area as a platform for private companies to join. The park area is allocated for waste treatment, which makes it ideal for companies to have their own waste treatment-related streams and operations there. The public waste management company is therefore an organizer in the ecosystem as it provides infrastructure and space for individual companies to be considered. This is done with a facilitative mode, as the central organization does not necessarily interact or intervene with the private companies but allows them to have their individual ongoing operations. However, the central organization still coordinates the ecosystem actions on the system level as an operator with a facilitative mode. It, for example, has an administrative office that coordinates the actions, passes, and visitors in the park area. The central organization is also a supporter with a facilitative mode when it has, for example, applied project funding for developing the ecosystem services, developed models for deepening the collaboration between the ecosystem members, and offered education for the members and local citizens as well. As the central organization is a public company, its funding comes from the local cities that have the role of a financer. The funding is primarily for handling the public waste treatment obligations, meaning the financer has a dirigiste mode. The central organization's public background also affects the policies and regulations implemented in the ecosystem. The national government is the regulator with a dirigiste mode, as the national laws on waste treatment directly guide the actions of the ecosystem members. The local cities implement policies toward the ecosystem through the public waste management company. However, within the ecosystem, the policies are not so binding, and the park members act very independently. The local city authorities therefore have the role of policymaker with a facilitative mode.

In Case 2-Rusko Waste Treatment Centre, the whole industrial CE ecosystem builds around a public waste treatment center and its operations. Thus, the actions taking place within the ecosystem are basically internal actions and projects of this central organization. Here, the ecosystem has emerged around a public waste management company and its processing area. The local municipality has 
in due time created the public waste management company and area in order to perform its legal obligations to handle public waste management. Therefore, the local municipality has the roles of an organizer and policymaker with a dirigiste mode, as the ecosystem has been created to fulfill the local needs of public waste management. The policies guiding the industrial CE ecosystem are closely related to the national legislation on waste management. The operations in the ecosystem are based on these laws, as the meaning is to fulfill the legal obligations. Thus, the national government has the role of a regulator with a dirigiste mode through the national waste management laws. As the functions of the ecosystem are organized around the public waste management company and its legal obligations, this central organization is also in the role of an operator. The central organization itself does not seem to possess many means for enhancing ecosystem actions because of the strict legislation that does not allow it to have so many openings outside of its main duties. However, the company has a facilitative mode, as it is a platform companies can join in order to get their waste streams processed alongside the streams from public waste management. The central organization is naturally also responsible for the processing facilities, equipment, and services in the area, giving it the role of a supporter with a dirigiste mode. The central organization invests yearly in several CE development projects. The public waste management company itself is funded by the revenues from waste disposal fees, meaning the central organization is also a financer with a dirigiste mode.

In Case 3-ECO3 Kolmenkulma Eco-Industrial Park, there are two main public actors with multiple roles in the industrial CE ecosystem, namely the local municipality and public development company owned by the municipality. Here, the ecosystem is seen as a way to enhance the business opportunities and vitality of the local municipality, meaning the local municipal government has the role of a policymaker with a dirigiste mode as there is a clear public agenda behind the ecosystem. Alongside the local policies, the actions of the public actor in the ecosystem must also be aligned with the overall local and national legislation defining the frames for public agency in such contexts. This means that the national government is present in the form of a regulator with a facilitative mode, as there are necessarily no direct but general laws guiding the industrial CE ecosystem. The ecosystem itself is a collaboration platform offered for private actors by the local municipality through the development company it owns. This way, the municipality is an organizer with a facilitative mode, as it has created the infrastructure for the ecosystem but is not directly organizing the ecosystem. The development company is the central organization of the ecosystem and in charge of the ecosystem operations, giving it the role of an operator. Although the central organization has a very partner-like mentality toward the private companies, the mode is still dirigiste, as the company negotiates with the companies that wish to be located in the industrial CE ecosystem and, for example, presumes the attendees to have a well-designed, established, and active business model. However, the central organization also has the role of a supporter with a facilitative mode as it aims to enhance the business opportunities of the ecosystem members. It inter alia offers meetings where the members can meet each other, share information and guide the companies with funding applications. The public development company is directly funded by the local city, meaning the city has the role of a financer with a dirigiste mode.

In Case 4-Topinpuisto Circular Economy Hub, the industrial CE ecosystem has emerged within an old public landfill area. There are a public waste management company as a central organization and private waste management companies located in the area. Although they operate quite independently, the waste management company has the role of an operator and organizer with a facilitative mode, as it has taken an active role toward developing a common vision and brand for the area. This central organization sees the park as a platform enabling private actors to carry out their sustainability-enhancing business. Moreover, it sees the ecosystem alongside the physical area to also cover the broader network of related actors. For this ecosystem, the central organization has, alongside its obligatory waste treatment duties, offered services, such as meeting rooms and joint events. In this role of a supporter with a facilitative mode, the central organization has also, for example, applied external funding for creating a visitor center in the area. The local city government is the financer of the public waste management company. The funding being direct, the mode is dirigiste. The public waste 
management company is to fulfill the public policies and duties, but the local city does not actively guide the ecosystem actions, giving it the role of a policymaker with a facilitative mode. The national waste treatment laws also directly guide the public waste management company, but because the private companies in the area are not so dependent on the central organization, the regulation appears for the ecosystem mainly as guidelines. The national government therefore has the role of a regulator with a facilitative mode.

\section{Discussion}

\subsection{Summary of the Key Results}

Through Studies 1 and 2 and the three research questions, public agency in industrial CE ecosystems has been examined broadly. The results contribute to earlier management and organization studies (such as $[16,17,35])$. That is, the studies go into detail in the nature and ways of collaboration of the public actor in industrial CE ecosystems: The roles define the nuances of the public actor, the modes represent the nature of relationships in the roles, and the organization structure evaluation provides knowledge on the system level. This way, the study has further defined in what kind of mechanisms and interfaces public agency can occur in industrial CE ecosystems. Moreover, these findings are assumed to be generalizable to consider public agency in CE more broadly with certain limitations.

RQ1: What roles can a public actor have in an industrial CE ecosystem? For now, knowledge about bringing CE into practice is still scarce [76], and there is a call for study on different agencies in $\mathrm{CE}$ and their roles in this transition. This also considers the public sector, and study on the roles of the public sector in CE ecosystems is needed [18]. The presented study responds to this call as six different roles-operator, organizer, financer, supporter, policymaker, regulator-for public actors in industrial CE ecosystems were identified and described in detail.

RQ2: What are the relationship modes a public actor can have toward an industrial CE ecosystem? Currently, there is a call for better exploration of the forms of collaboration and innovations among different $C E$ actors (e.g., $[6,16])$. The identified modes—facilitative and dirigiste-represent the nature of interaction a public actor can have toward and with an industrial CE ecosystem. The two modes indicate that the roles of public actors differ from each other based on the level (direct-indirect) and way (definitive-supportive) of involvement in the industrial CE ecosystem actions. It cannot still be stated whether one mode would be superior to another. In fact, a mix of both modes is likely to occur within an industrial CE ecosystem - an argument similar to Yu et al.'s [21] suggestion for public actors to promote EIPs with a mix of planned and facilitated approaches. Overall, the facilitative mode represents indirect, supportive, and stimulating means to enhance $\mathrm{CE}$, whereas the dirigiste mode is about direct, definitive, and suggestive means to promote CE.

RQ3: In what kind of actor structures may the public actor roles and modes occur in an industrial CE ecosystem? Knowledge about industrial CE ecosystems, their lifecycles, and types is still scarce [17]. The examination of the recognized roles and modes in four Finnish industrial CE ecosystem cases in Section 4.3 showed the organizational structures the different roles may result in and therefore extended the findings presented in Section 4.1. That is, the six roles were first constructed by combining examples from the literature (Study 1), after which the empirical case studies (Study 2) examined how the different roles emerge within the same ecosystem.

Moreover, the examination revealed further details about how the roles of public agency actualize and can be situated in an industrial CE ecosystem (see Figures 1 and 2). Based on the study: The organizer is a local municipality where the ecosystem is physically located or the central organization of the system, meaning it is situated somewhere midway of the industrial CE ecosystem. The regulator (e.g., the national government, a ministry) is usually positioned outside of the ecosystem and on another, often macro level. Namely, national or regional policies are usually not directly targeted to just one industrial CE ecosystem, but rather intended to create the overall legal context for businesses. However, it can be asked whether the distance between the regulator and CE companies is too great to enhance 
the flexible and CE-encouraging context. In the four cases, the operator was usually the public waste management company with its large side streams, resource flows, and legal obligations. In each case, the public operator was also the central organization of the ecosystem, and the operator is therefore located in the center of the industrial CE ecosystem. The link between the operator and financer is very strong as the operators were all publicly owned companies in the studied cases. The financer is located on the outer edge of the industrial CE ecosystem, somewhere between meso and macro level, since the funding to the central organization comes from a local municipality or city. Owners and public institutions are situated closer to the ecosystem while, for example, international, research, and education institutes are at the outer edge of the ecosystem. The central organization acting as the operator is often also the supporter of the ecosystem. This seems logical, as the central organization is responsible for the operations and development of the ecosystem. The supporter is often located within the ecosystem itself, providing the supporter with hands-on knowledge about the needs of the ecosystem members. The local city or municipality government is the policymaker with its national waste treatment-related obligations, and aims to improve the local societal welfare through environmental and economic aspects. Therefore, the policymaker is in the immediate presence of the outer edge of the ecosystem or even in the center of the ecosystem when it guides the central organization.

\subsection{Theoretical Contribution}

There is a call for deeper examination of $\mathrm{CE}$, circular business models, and the forms of collaboration and different roles in industrial CE ecosystems (e.g., $[16,18])$. This study responds to the call as it offers novel information and guidance on how public agency can actualize in such ecosystems and promote sustainability-oriented CE operations and innovations in the interface between the public and private sectors. This is needed as sustainability transition requires clear roles and co-operation between the public and private sectors, as well as between society and citizens in the CE development process $[2,5,6]$. Indeed, this study has taken a step toward a multidisciplinary approach to industrial $\mathrm{CE}$ ecosystems, since public agency and some related viewpoints from political and social ecology have been discovered in the field of industrial ecology. This further contributes to the call for bridging management, organizational, policy, and social studies to engineering and natural sciences-dominant industrial ecology $[66,77]$. Apart from social studies and in addition to the industrial ecology field, the public actor was studied here as a part of the economic-technological structure of industrial $\mathrm{CE}$ ecosystems, i.e., how public actor involvement manifests and is organized in the public-private interface within an industrial CE ecosystem. Furthermore, the study provides a picture of the current ways in which public actors interact with private actors in industrial CE ecosystems. By making the mechanisms more visible and unveiling the practical manifestations of the earlier recognized (see $[13,17])$ public actor role in $\mathrm{CE}$, the study provides better means for managing public-private collaboration and therefore sustainability transitions.

Public agency in industrial CE ecosystems should be considered a multidimensional phenomenon: As this study shows, the same public actor can have several roles simultaneously within the same ecosystem, or there can be several public actors (e.g., public companies, municipality, public authorities) within the same ecosystem with the same or different roles. However, the roles can also be very strongly centralized for a few public actors (as the results in Section 4.3 indicate). The roles still explain public agency in industrial CE ecosystems: they show the means a public actor can use and the nature of the public actor in industrial CE ecosystems.

There seems to be two main ways for public actors to pursue CE: the so-called facilitative and dirigiste approaches. Indeed, this distinction on the micro level seems to reproduce the two types of influence on the macro level, i.e., "better environment as a spin-off from business" and "business based on CE" CE strategies (see, e.g., [37]). Moreover, it seems there is a connection between the modes and the strategies. In the studied "better environment as a spin-off from business" cases, facilitative and dirigiste public agency modes are used, whereas mainly dirigiste mode is used in the "business based on CE" cases. The roles of policymaker, organizer, and operator all with facilitative mode 
were highlighted in the "better environment as a spin-off from business" cases. Correspondingly, the roles of operator, policymaker, and regulator with dirigiste mode were highlighted in the "business based on CE" cases. The sample being relatively small and the division of cases between the two CE strategies not clear-cut (like in the case of Kawasaki Zero-Emission Industrial Complex [39] described in Section 2.1), these are only early interpretations. Furthermore, the facilitative and dirigiste approaches represent the two ends of a continuum rather than being dichotomous. On this scale, several emphases that are mixes of both facilitative and dirigiste approaches can occur. Furthermore, the same public actor can have different modes in different roles or even within the same role.

\subsection{Practical Implications}

This research has concrete practical implications for public actors and practitioners of industrial $\mathrm{CE}$ ecosystems as well. For public authorities and policymakers, the study provides a structured view of public agency in industrial CE ecosystems by discovering avenues and modes of interaction for public contribution in the ecosystems. Through the recognized roles, the public actor can pursue sustainable actions in a facilitative or dirigiste manner. Moreover, the categorization table (Table 3) regarding the roles and modes of a public actor provides a library of actions and means that public authorities can consider when planning their sustainability agendas. The explicitly stated public actor roles (Section 4.1.) help public authorities to self-reflect their ways of interaction and ensure that the societal context for new CE business openings would be as supportive as possible.

For industrial CE ecosystem administrators as well as practitioners developing collaboration in industrial CE ecosystems, this study makes the public actor roles visible (Section 4.1. and Figures 1 and 2), and this way may help the private actors recognize new ways for mutual co-creation, lowering the obstacles to public-private interaction. With a well-structured phenomenon, it is easier for the managers to approach $\mathrm{CE}$ and plan how to develop new $\mathrm{CE}$ innovations with the contribution of a public actor. This way, new innovative industrial CE ecosystems can occur in a collaborative manner. Overall, all CE ecosystems operate in a public context, which is why it is valuable for any business to know the nuances of public agency, i.e., the public principles affecting their operating environment.

\subsection{Limitations}

The presented research includes some limitations embedded in the chosen research focus and methods. First, the context of this paper allowed only a limited number of cases to be studied. The identified roles may not be all-inclusive, but they still show the broad spectrum of public roles in industrial CE ecosystems. Moreover, the cases represent a sample of EIPs around the world, increasing the generalizability of the roles across regions (although country-specific variances may occur, e.g., in the incidence of certain roles).

Similarly, the recognized public actors in the Finnish cases presented in Section 4.3 are likely not all-inclusive, but still the most prevalent ones in those ecosystems. They also show the multidimensionality of the public agency (several public actors with different/similar roles) and confirm that the presence of public agency in industrial CE ecosystems can be multi-faceted (varying means for involvement). The manifestations of each role in Section 2 should instead be examined with caution: The cases in Study 2 are from Finland, meaning the results presented in Section 4.3 are under the influence of context-specific factors present in each case. For example, land scarcity is not an issue in Finland, whereas in some other countries it might be a prevalent driver guiding public policies and interests.

As the aim was to broadly study the possible roles and modes of public agency, a deliberate choice was made to manually emphasize cases from Asia in the sample in order to have an equal representation of Asian and Western cases in Study 1. This is because these areas were considered to represent the two major (opposite) CE strategies and public agency viewpoints. The four cases for the study on organization structures in Study 2 were all chosen from Finland, as they were easily 
accessible and known to have significant public activity within them. With different source material available and different individuals doing the study, different cases could have been selected.

The 20 international cases in Study 1 were studied through the latest source material available online and can be deemed reliable with reasonable certainty. However, some of the material is over ten years old, meaning that the state of the industrial CE ecosystem may have changed considerably since the release of the material. This does still not restrict the study, as the aim was to examine a snapshot of public agency in each case. In other words, the aim was to examine what kinds of forms of public agency have existed during a certain period of time. This is in line with qualitative content analysis, which aims to create a picture of a given phenomenon that is always contextual, not objective [78]. This, however, means that no interpretations about the temporal incidence and development of public agency can be made on the basis of the Study 1 cases.

Moreover, this paper purposefully concentrates on public agency in the nexus of industrial ecology and organization studies and examines public actors in industrial CE ecosystems as a part of the economic-technological structure in the business interface, seen from companies' point of view, i.e., there remain uncharted areas in industrial CE ecosystems to be discovered by other disciplines. Perhaps most importantly, industrial CE ecosystems related to social and economic sustainability dimensions and aspects of actors other than public ones or companies remain virtually intact in this paper.

\section{Future Research}

This study does not try to present an all-inclusive theoretical background, but essential elements of public agency in industrial CE ecosystems. The provided framework serves indeed as a grounding for further research, as it covers a variety of themes whose generalizability to a broader CE context could also be explored within the industrial ecology field and by other disciplines. The field of CE and related agencies is ever-changing and developing, and similar research with a bigger sample would enhance the generalizability of the results into a broader global context, from public agency in industrial CE ecosystems toward public agency in CE in general. Furthermore, the Study 1 cases would deserve a deeper examination in order to explore the global variation, diversity, and actual presence of the public actor roles in detail. In this study, the Study 1 cases now served as sketches for public actor roles and modes examined in detail in Study 2.

More studies are also needed for further developing the findings of this paper: How do the different roles of a public actor within the same system affect each other? What kind of practical effects do the modes facilitative and dirigiste have, i.e., do they result in principle in different outcomes? Furthermore, the continuum between the modes could be complemented with the "passive" mode, if further studies support this. Similarly, a series of longitudinal studies made with up-to-date data would provide valuable insights into the temporal nature of public agency.

For recognizing best practices for industrial CE ecosystem development as collaboration between public and private actors, context-specific factors cannot be ignored. The history of the area and local community needs to be considered while planning and developing the operations of an industrial CE ecosystem [23]. The writers see industrial CE ecosystems as entities inseparable from their local urban and societal contexts. However, this study concentrated on public agency and actions happening within certain territories and did not discover the meaning of space, i.e., place-specificity itself (e.g., context-specific factors affecting an ecosystem, how the physical and abstract space is perceived by the ecosystem members). Moreover, related to material stocks and flows, it is also important that public actors consider the notion of place variously between different materials and have separate policies for the materials: As the feasibility radius of the material flows differ (e.g., rare minerals available only as exported aboard vs. plastics produced and consumed in high volumes locally), public policies for the materials must also differ. Although in general, the aim in CE is to utilize resources as locally as possible and it seems rather logical that the industrial CE ecosystems that acknowledge and therefore utilize place-specific issues, such as opportunities for symbiotic benefits within a certain territory, are more likely to succeed, this calls for future research on the topic. 
In the future, more industrial CE ecosystems will be located in urban areas or even be urban areas themselves. Here, the public actor can offer or function as a platform for inter-organizational collaboration (e.g., material stocks of construction material or a digital platform for knowledge exchange on available current side streams). This platform approach deserves more future research. Green Transit-Oriented Development (Green TOD) would be one avenue for studying the topic, as it offers a strategy model for regional industrial CE ecosystem development.

With strategic planning (see [23]), industrial CE ecosystems can enable and enhance the sustainable practices and sustainable development of the region they are located in, for example by identifying possibilities toward and benefits of symbiotic transactions in CE, revitalizing economic life, increasing co-operation between companies, and providing new business possibilities. The examination of these possibilities should also include the aspects of social sustainability. Some justice, democracy, and equity-related challenges have been seen in material flows (see [4]), but this paper has not examined public agency from the governance and social sciences point of view. Next, the social dimensions of sustainability could be discovered and public agency examined against these dimensions. There are multiple issues related to the public actor as a local authority possessing regional power, for example how different stakeholders are included and treated in public CE planning. Public actors have power and influence in societies, and therefore it is important to consider who public actors represent and how they use their power.

Social sustainability also includes addressing the different actors in (industrial) CE ecosystems. For example, Figures 1 and 2 show how the examined industrial CE ecosystems consider a wide range of actors, such as companies, kindergartens, households, associations, and universities. Future studies could therefore examine, for example, what kind of power structures and issues emerge among the different actors and stakeholders of $\mathrm{CE}$, which roles different stakeholders can have, and whether the recognized public actor roles be performed as such or in an adapted manner by private sector actors as well.

Finally, material security has recently arisen to a new spotlight with the COVID-19 pandemic, as the supply of many resources, such as medical and protective equipment and even groceries, became extremely challenging due to the sudden increase in demand. Material security became a large public challenge, and public actors are very interested in reducing material security risks and gaining resiliency toward crises, such as possible future pandemics or cataclysms. The public actor roles, modes, and structures provided in this study may serve as future avenues for public actors to acknowledge the current and future realities and build resilience toward material security risks.

Author Contributions: Conceptualization, J.U. and L.A.-S.; methodology, J.U. and H.V.; validation, J.U. and H.V.; formal analysis, J.U. and H.V.; writing — original draft preparation, J.U. and H.V.; writing-review and editing, J.U., H.V. and L.A.-S.; visualization, H.V. All authors have read and agreed to the published version of the manuscript.

Funding: This research was funded by the European Regional Development Fund through the projects entitled "Future circular economy hubs in Finland" (CircHubs) (grant ID A72829) and "Utilization of side streams and masses of soil in the cities" (CircVol) (grant ID A74186) and the Strategic Research Council, Academy of Finland through the project entitled "Circular Economy Catalysts: From Innovation to Business Ecosystems" (CICAT2025) (grant ID 320194).

Acknowledgments: We thank Piero Morseletto and the two anonymous reviewers for the highly valuable feedback and insights they provided for the different versions of the manuscript.

Conflicts of Interest: The authors declare no conflict of interest. The funders had no role in the design of the study; in the collection, analyses, or interpretation of data; in the writing of the manuscript, or in the decision to publish the results. 


\section{References}

1. Bocken, N.M.; De Pauw, I.; Bakker, C.; Van Der Grinten, B. Product design and business model strategies for a circular economy. J. Ind. Prod. Eng. 2016, 33, 308-320. [CrossRef]

2. Isaksson, K.; Heikkinen, S. Sustainability Transitions at the Frontline. Lock-in and Potential for Change in the Local Planning Arena. Sustainability 2018, 10, 840. [CrossRef]

3. Prendeville, S.; Cherim, E.; Bocken, N. Circular cities: Mapping six cities in transition. Environ. Innov. Soc. Transit. 2018, 26, 171-194. [CrossRef]

4. Marin, J.; De Meulder, B. Interpreting circularity. Circular city representations concealing transition drivers. Sustainability 2018, 10, 1310. [CrossRef]

5. Kębłowski, W.; Lambert, D.; Bassens, D. Circular economy and the city: An urban political economy agenda. Cult. Organ. 2020, 26, 142-158. [CrossRef]

6. Moreau, V.; Sahakian, M.; Van Griethuysen, P.; Vuille, F. Coming full circle: Why social and institutional dimensions matter for the circular economy. J. Ind. Ecol. 2017, 21, 497-506. [CrossRef]

7. Ghisellini, P.; Cialani, C.; Ulgiati, S. A review on circular economy: The expected transition to a balanced interplay of environmental and economic systems. J. Clean. Prod. 2016, 114, 11-32. [CrossRef]

8. Korhonen, J. Four ecosystem principles for an industrial ecosystem. J. Clean. Prod. 2001, 9, 253-259. [CrossRef]

9. Bruel, A.; Kronenberg, J.; Troussier, N.; Guillaume, B. Linking Industrial Ecology and Ecological Economics: A Theoretical and Empirical Foundation for the Circular Economy. J. Ind. Ecol. 2019, 23, 12-21. [CrossRef]

10. Korhonen, J.; Honkasalo, A.; Seppälä, J. Circular Economy: The Concept and its Limitations. Ecol. Econ. 2018, 143, 37-46. [CrossRef]

11. Velenturf, A.P.M. Initiating resource partnerships for industrial symbiosis. Reg. Stud. Reg. Sci. 2017, 4, 117-124. [CrossRef]

12. Mulrow, J.S.; Derrible, S.; Ashton, W.S.; Chopra, S.S. Industrial Symbiosis at the Facility Scale. J. Ind. Ecol. 2017, 21, 559-571. [CrossRef]

13. Gibbs, D.; Deutz, P. Reflections on implementing industrial ecology through eco-industrial park development. J. Clean. Prod. 2007, 15, 1683-1695. [CrossRef]

14. Aarikka-Stenroos, L.; Ritala, P.; Thomas, L.D.W. Circular economy ecosystems: A typology, definitions, and implications. In Handbook of Sustainability Agency; Teerikangas, S., Onkila, T., Koistinen, K., Mäkelä, M., Eds.; Edgar Elgar: Cheltenham/Camberley, UK, 2021; pp. 15-37, in press.

15. Paquin, R.L.; Howard-Grenville, J. Blind Dates and Arranged Marriages: Longitudinal Processes of Network Orchestration. Organ. Stud. 2013, 34, 1623-1653. [CrossRef]

16. Zucchella, A.; Previtali, P. Circular business models for sustainable development: A "waste is food" restorative ecosystem. Bus. Strategy Environ. 2019, 28, 274-285. [CrossRef]

17. Chertow, M.; Ehrenfeld, J. Organizing Self-Organizing Systems. J. Ind. Ecol. 2012, 16, 13-27. [CrossRef]

18. Fratini, C.; Georg, S.; Jørgensen, M. Exploring circular economy imaginaries in European cities: A research agenda for the governance of urban sustainability transitions. J. Clean. Prod. 2019, 228, 974-989. [CrossRef]

19. Bellantuono, N.; Carbonara, N.; Pontrandolfo, P. The organization of eco-industrial parks and their sustainable practices. J. Clean. Prod. 2017, 161, 362-375. [CrossRef]

20. Yu, F.; Han, F.; Cui, Z. Evolution of industrial symbiosis in an eco-industrial park in China. J. Clean. Prod. 2015, 87, 339-347. [CrossRef]

21. Yu, C.; Dijkema, G.P.J.; de Jong, M. What Makes Eco-Transformation of Industrial Parks Take Off in China? J. Ind. Ecol. 2015, 19, 441-456. [CrossRef]

22. Cervero, R.; Sullivan, C. Green TODs: Marrying transit-oriented development and green urbanism. Int. J. Sustain. Dev. World Ecol. 2011, 18, 210-218. [CrossRef]

23. Qviström, M.; Bengtsson, J. What Kind of Transit-Oriented Development? Using Planning History to Differentiate a Model for Sustainable Development. Eur. Plan. Stud. 2015, 23, 2516-2534. [CrossRef]

24. Milan, B. How participatory planning processes for transit-oriented development contribute to social sustainability. J. Environ. Sci. 2016, 6, 520-524.

25. Ranta, V.; Aarikka-Stenroos, L.; Ritala, P.; Mäkinen, S.J. Exploring institutional drivers and barriers of the circular economy: A cross-regional comparison of China, the US, and Europe. Resour. Conserv. Recycl. 2018, 135, 70-82. [CrossRef] 
26. Schöggl, J.P.; Stumpf, L.; Baumgartner, R.J. The narrative of sustainability and circular economyA longitudinal review of two decades of research. Resour. Conserv. Recycl. 2020, 163, 105073. [CrossRef]

27. Antikainen, M.; Aminoff, A.; Kettunen, O.; Sundqvist-Andberg, H.; Paloheimo, H. Circular Economy Business Model Innovation Process-Case Study. Sustain. Des. Manuf. 2017, 68, 546-555.

28. Patala, S.; Hämäläinen, S.; Jalkala, A.; Pesonen, H.-L. Towards a broader perspective on the forms of eco-industrial networks. J. Clean. Prod. 2014, 82, 166-178. [CrossRef]

29. Wang, Q.; Deutz, P.; Chen, Y. Building institutional capacity for industrial symbiosis development: A case study of an industrial symbiosis coordination network in China. J. Clean. Prod. 2017, 142, 1571-1582. [CrossRef]

30. Herczeg, G.; Akkerman, R.; Hauschild, M.Z. Supply chain collaboration in industrial symbiosis networks. J. Clean. Prod. 2018, 171, 1058-1067. [CrossRef]

31. Ruggieri, A.; Braccini, A.M.; Poponi, S.; Mosconi, E.M. A meta-model of interorganisational cooperation for the transition to a circular economy. Sustainability 2016, 8, 1153. [CrossRef]

32. Lowe, E.A.; Evans, L.K. Industrial ecology and industrial ecosystems. J. Clean. Prod. 1995, 3, 47-53. [CrossRef]

33. Yu, C.; Dijkema, G.P.J.; de Jong, M.; Shi, H. From an eco-industrial park towards an eco-city: A case study in Suzhou, China. J. Clean. Prod. 2015, 102, 264-274. [CrossRef]

34. Mathews, J.A.; Tan, H. Progress toward a Circular Economy in China: The Drivers (and Inhibitors) of Eco-industrial Initiative. J. Ind. Ecol. 2011, 15, 435-457. [CrossRef]

35. Ingstrup, M.B.; Aarikka-Stenroos, L.; Adlin, N. When institutional logics meet: Alignment and misalignment in collaboration between academia and practitioners. Ind. Mark. Manag. 2020, in press. [CrossRef]

36. Zeng, H.; Chen, X.; Xiao, X.; Zhou, Z. Institutional pressures, sustainable supply chain management, and circular economy capability: Empirical evidence from Chinese eco-industrial park firms. J. Clean. Prod. 2017, 155, 54-65. [CrossRef]

37. McDowall, W.; Geng, Y.-J.; Huang, B.; Barteková, E.; Bleischwitz, R.; Türkeli, S.; Kemp, R.; Doménech, T. Circular Economy Policies in China and Europe. J. Ind. Ecol. 2017, 21, 651-661. [CrossRef]

38. Park, J.; Sarkis, J.; Wu, Z. Creating integrated business and environmental value within the context of China's circular economy and ecological modernization. J. Clean. Prod. 2010, 18, 1494-1501. [CrossRef]

39. Van Berkel, R.; Fujita, T.; Hashimoto, S.; Fujii, M. Quantitative Assessment of Urban and Industrial Symbiosis in Kawasaki, Japan. Environ. Sci. Technol. 2009, 43, 1271-1281. [CrossRef]

40. Morseletto, P. Targets for a circular economy. Resour. Conserv. Recycl. 2020, 153, 104553. [CrossRef]

41. Fischer, A.; Pascucci, S. Institutional incentives in circular economy transition: The case of material use in the Dutch textile industry. J. Clean. Prod. 2017, 155, 17-32. [CrossRef]

42. Walls, J.L.; Paquin, R.L. Organizational Perspectives of Industrial Symbiosis: A Review and Synthesis. Organ. Environ. 2015, 28, 32-53. [CrossRef]

43. Teece, D.J. Business Models, Business Strategy and Innovation. Long Range Plan 2010, 43, 172-194. [CrossRef]

44. Parida, V.; Wincent, J. Why and how to compete through sustainability: A review and outline of trends influencing firm and network-level transformation. Int. Entrep. Manag. J. 2019, 15, 1-19. [CrossRef]

45. Górecki, J.; Núñez-Cacho, P.; Corpas-Iglesias, F.A.; Molina, V. How to convince players in construction market? Strategies for effective implementation of circular economy in construction sector. Cogent Eng. 2019, 6, 1690760. [CrossRef]

46. Cerreta, M.; Di Girasole, E.G.; Poli, G.; Regalbuto, S. Operationalizing the Circular City Model for Naples' City-Port: A Hybrid Development Strategy. Sustainability 2020, 12, 2927. [CrossRef]

47. Laumann, F.; Tambo, T. Enterprise architecture for a facilitated transformation from a linear to a circular economy. Sustainability 2018, 10, 3882. [CrossRef]

48. Nogueira, A.; Ashton, W.; Teixeira, C.; Lyon, E.; Pereira, J. Infrastructuring the Circular Economy. Energies 2020, 13, 1805. [CrossRef]

49. Robson, C. Real World Research: A Resource for Social Scientists and Practitioner Researchers; Blackwell: Oxford, UK, 1994.

50. Eisenhardt, K.M.; Graebner, M.E. Theory building from cases: Opportunities and challenges. Acad. Manag. J. 2007, 50, 25-32. [CrossRef]

51. Patton, M.Q. Qualitative Research \& Evaluation Methods: Integrating Theory and Practice, 4th ed.; SAGE: Los Angeles, CA, USA, 2015.

52. Yu, C.; de Jong, M.; Dijkema, G.P.J. Process analysis of eco-industrial park development-the case of Tianjin, China. J. Clean. Prod. 2014, 64, 464-477. [CrossRef] 
53. Schilling, J. On the Pragmatics of Qualitative Assessment: Designing the Process for Content Analysis. Eur. J. Psychol. Assess. 2006, 22, 28-37. [CrossRef]

54. Erkman, S.; Van Hezik, C. Global Assessment of Eco-Industrial Parks in Developing and Emerging Countries; The United Nations Industrial Development Organization, Vienna International Centre: Vienna, Austria, 2016; Available online: https://www.unido.org/sites/default/files/2017-02/2016_Unido_Global_Assessment_of_Eco-Industrial_ Parks_in_Developing_Countries-Global_RECP_programme_0.pdf (accessed on 25 November 2020).

55. Yin, R.K. Case Study Research: Design and Methods, 4th ed.; Sage Publications: Thousand Oaks, CA, USA, 2009.

56. Liu, Z.; Adams, M.; Cote, R.P.; Geng, Y.; Li, Y. Comparative study on the pathways of industrial parks towards sustainable development between China and Canada. Resour. Conserv. Recycl. 2018, 128, 417-425. [CrossRef]

57. Veleva, V.; Todorova, S.; Lowitt, P.; Angus, N.; Neely, D. Understanding and addressing business needs and sustainability challenges: Lessons from Devens eco-industrial park. J. Clean. Prod. 2015, 87, 375-384. [CrossRef]

58. Liwarska-Bizukojc, E.; Bizukojc, M.; Marcinkowski, A.; Doniec, A. The conceptual model of an eco-industrial park based upon ecological relationships. J. Clean. Prod. 2009, 17, 732-741. [CrossRef]

59. Morikawa, M. Eco-Industrial Developments in Japan; Indigo Development Working Paper \#11; RPP International, Indigo Development Center: Emeryville, CA, USA, 2000.

60. Zhu, Q.; Lowe, E.A.; Wei, Y.-A.; Barnes, D. Industrial Symbiosis in China: A Case Study of the Guitang Group. J. Ind. Ecol. 2007, 11, 31-42. [CrossRef]

61. Jacobsen, N.B. Industrial Symbiosis in Kalundborg, Denmark: A Quantitative Assessment of Economic and Environmental Aspects. J. Ind. Ecol. 2006, 10, 239-255. [CrossRef]

62. Harris, S. Industrial Symbiosis in the Kwinana Industrial Area (Western Australia). Meas. Control 2007, 40, 239-244. [CrossRef]

63. Yang, S.; Feng, N. A case study of industrial symbiosis: Nanning Sugar Co., Ltd. in China. Resour. Conserv. Recycl. 2008, 52, 813-820. [CrossRef]

64. Elabras Veiga, L.B.; Magrini, A. Eco-industrial park development in Rio de Janeiro, Brazil: A tool for sustainable development. J. Clean. Prod. 2009, 17, 653-661. [CrossRef]

65. Geng, Y.; Liu, Z.; Xue, B.; Dong, H.; Fujita, T.; Chiu, A. Emergy-based assessment on industrial symbiosis: A case of Shenyang Economic and Technological Development Zone. Environ. Sci. Pollut. Res. 2014, 21, 13572-13587. [CrossRef]

66. Korhonen, J. Theory of industrial ecology: The case of the concept of diversity. Prog. Ind. Ecol. Int. J. 2005, 2, 35-72. [CrossRef]

67. Park, H.-S.; Won, J.-Y. Ulsan Eco-industrial Park: Challenges and Opportunities. J. Ind. Ecol. 2007, 11, 11-13. [CrossRef]

68. Valentino, A. Eco-industrial parks: The international state of art. In Eco-Industrial Parks: A Green and Place Marketing Approach; Caroli, M., Cavallo, M., Valentino, A., Eds.; Luiss University Press: Rome, Italy, 2015; pp. 21-42.

69. Chinn, P.L.; Kramer, M.K. Theory and Nursing: A Systematic Approach, 5th ed.; Mosby Year Book: St. Louis, MO, USA, 1999.

70. Ayres, L.; Knafl, K.A. Typological Analysis. In The SAGE Encyclopedia of Qualitative Research Methods; Given, L.M., Ed.; SAGE Publications, Inc.: Thousand Oaks, CA, USA, 2012; pp. 901-902.

71. Kluge, S. Empirically Grounded Construction of Types and Typologies in Qualitative Social Research. Forum Qual. Soc. Res. 2000, 1. [CrossRef]

72. Finnish Road Map to a Circular Economy 2016-2025. Available online: https://www.sitra.fi/en/projects/ leading-the-cycle-finnish-road-map-to-a-circular-economy-2016-2025/ (accessed on 2 June 2020).

73. Sitra honoured as a Leading Driver of the Circular Economy. Available online: https://www.sitra.fi/en/news/ sitra-honoured-leading-driver-circular-economy-can-world-learn-finland/ (accessed on 2 June 2020).

74. Kalundborg Symbiosis. Available online: http://www.symbiosis.dk/en/ (accessed on 16 February 2019).

75. Geng, Y.; Xinbei, W.; Qinghua, Z.; Hengxin, Z. Regional initiatives on promoting cleaner production in China: A case of Liaoning. J. Clean. Prod. 2010, 18, 1502-1508. [CrossRef]

76. Leising, E.; Quist, J.; Bocken, N. Circular Economy in the building sector: Three cases and a collaboration tool. J. Clean. Prod. 2018, 176, 976-989. [CrossRef] 
77. Korhonen, J.; von Malmborg, F.; Strachan, P.A.; Ehrenfeld, J.R. Management and policy aspects of industrial ecology: An emerging research agenda. Bus. Strategy Environ. 2004, 13, 289-305. [CrossRef]

78. White, M.D.; Marsh, E.E. Content Analysis: A Flexible Methodology. Libr. Trends 2006, 55, 36-45. [CrossRef]

Publisher's Note: MDPI stays neutral with regard to jurisdictional claims in published maps and institutional affiliations.

(C) 2020 by the authors. Licensee MDPI, Basel, Switzerland. This article is an open access article distributed under the terms and conditions of the Creative Commons Attribution (CC BY) license (http://creativecommons.org/licenses/by/4.0/). 